Article

\title{
Feasibility Study of Biogas Production from Hardly Degradable Material in Co-Inoculated Bioreactor
}

\author{
Spyridon Achinas * and Gerrit Jan Willem Euverink \\ Faculty of Science and Engineering, University of Groningen, Nijenborgh 4, 9747 AG Groningen, \\ The Netherlands; g.j.w.euverink@rug.nl \\ * Correspondence: s.achinas@rug.nl; Tel.: +31-50-363-9203
}

Received: 27 February 2019; Accepted: 15 March 2019; Published: 18 March 2019

\begin{abstract}
Anaerobic technology is a well-established technique to wean the fossil fuel-based energy off with various positive environmental inferences. Biowaste treatment is favorable due to its low emissions. Biogas is merely regarded as the main product of anaerobic digestion with high energy value. One of the key concerns of the waste water treatment plants is the vast amount of cellulosic residuals produced after the treatment of waste waters. The fine sieve fraction, collected after the primary sludge removal, has great energy value. In this study, the economic performance of a biogas plant has been analyzed based on net present value and pay-back period concepts. The plant in the base scenario produced $309,571 \mathrm{~m}^{3}$ biogas per year. The annual electricity production has been $390,059 \mathrm{kWh}$. The producible heat energy has been $487,574 \mathrm{kWh}$ or $1755 \mathrm{GJ}$ per year. The plant depicts a positive economic situation with 11 years pay-back time, earning low profits and showing a positive net present value of $11,240 €$.
\end{abstract}

Keywords: anaerobic digestion; fine sieve fraction; financial modeling; biogas plant

\section{Introduction}

Current environmental and political pressures, the wobbling price of the fuels, and the depleted energy derived from fossil fuel reserves such as crude oil, coal, and natural gas have increased the industrial focus to bioenergy derived from biowaste, and encouraged technological progress in the biogas production sector in the EU [1-3]. In the Netherlands, a vast amount of waste water is yearly treated in WWTPs. Several abatement techniques are applied to treat organic waste, with the anaerobic digestion (AD) technology being widely used for biogas production [4-6].

The $\mathrm{AD}$ process comprises four main steps: hydrolysis, acidogenesis, acetogenesis, and methanogenesis. During AD, bioenergy is produced in the form of a gaseous fuel, the so-called biogas, with an approximate composition of $66 \% \mathrm{CH}_{4}, 33 \% \mathrm{CO}_{2}, 0.5 \% \mathrm{~N}_{2}, 0.1 \% \mathrm{O}_{2}$, and $103 \mathrm{mg} / \mathrm{L}$ biogas $\mathrm{H}_{2} \mathrm{~S}[7,8]$. Biogas can be used for electricity and heat generation or as a vehicle fuel [9-11]. Several studies focus on the potential of biogas in fuel cell systems [12,13]. AD is an appealing technique playing a key role in the bioenergy sector within the EU [14-17]. Co-digestion had been extensively investigated and reported as an alternative solution to treat simultaneously various waste streams $[18,19]$. The benefit from co-digestion is that the optimal carbon to nitrogen $(\mathrm{C}: \mathrm{N})$ ratio (20:1 to 30:1) can be arranged by mixing different substrates.

However, an alternative technique was recently reported for the improvement of AD performance. Co-inoculation with two or more inocula provides a vast and wide consortium of microorganism within the bioreactor [20]. The source of the microbial inoculum will influence the degradation efficiency, the bioreactor stability as well as the biogas yield and composition [21-23]. A preceding study cited that the inoculum also provided macro- and micronutrients enhancing the microbial activity and thus augmenting the biogas yield [24]. To date, materials recovery and energy management are 
pivotal issues to corroborate sustainability $[25,26]$. Organic material, rich in cellulosic residuals, can be collected with sieves from the influent of a waste water treatment plants [27]. These residuals or FSF can be digested in anaerobic digesters for energy recovery [28].

This study continues the work of Achinas and Euverink [20] and focusses on the feasibility of combined inoculation through experimental tests and financial assessment. Cash flow analysis was performed to evaluate the viability of a biogas plant. PFSF was selected as substrate and two different inocula were used in the experiments. The biogas yield, methane content, $\mathrm{pH}$, redox, FAN and FOS/TAC ratio were determined to assess the efficiency of the co-inoculation. It is notable that a techno-economic assessment on the treatment of PFSF has not been previously conducted and reported, thus this study may provide new realistic insight on the exploitation of a different waste material. The two specific objectives of this study were to (1) evaluate the AD performance of co-inoculated bioreactors treating PFSF in semi-continuous mode and (2) examine the profitability of pilot biogas unit treating PFSF in combination with co-inoculation using the NPV analysis.

\section{Materials and Methods}

\subsection{Inocula and Substrate}

The PFSF was obtained from the Blaricum sewage treatment plant in The Netherlands, and was stored at $6{ }^{\circ} \mathrm{C}$ to prevent possible hydrolysis. The inocula used in the experimental tests were collected from three different sources and their characteristics are shown in Table 1.

Table 1. Characteristics of the inocula and substrate used in the batch tests.

\begin{tabular}{ccccc}
\hline Parameter & Unit & IN1 & IN2 & PFSF \\
\hline $\mathrm{pH}$ & - & 7.52 & 7.27 & $\mathrm{ND}$ \\
$\mathrm{TS}$ & $\mathrm{g} \cdot \mathrm{kg}^{-1}$ & $47.3(0.8)$ & $112.9(1.5)$ & $202.4(12.9)$ \\
VS & $\mathrm{g} \cdot \mathrm{kg}^{-1}$ & $29.6(0.4)$ & $61.5(1.0)$ & $174.8(6.3)$ \\
$\mathrm{VS} / \mathrm{TS}$ & - & 0.63 & 0.55 & 0.94 \\
COD & $\mathrm{g} \cdot \mathrm{kg}^{-1}$ & $50.3(2.2)$ & $81.8(3.9)$ & $\mathrm{ND}$ \\
VS/COD & - & 0.59 & 0.75 & $\mathrm{ND}$ \\
\hline
\end{tabular}

IN1: digestate from reactor treating activated sludge, IN2: digestate from reactor treating organic fraction of MSW, ND: not determined. Values are the average of three determinations. In parentheses is given the standard deviation.

The first inoculum (IN1) was obtained from an anaerobic digester treating anaerobic activated sludge from the WWTP of Garmerwolden (Groningen, The Netherlands). The second inoculum (IN2) was collected from an anaerobic bioreactor treating the organic fraction of MSW in the MSW treatment plant of Attero (Groningen, The Netherlands). All inocula were stored at $6{ }^{\circ} \mathrm{C}$ to maintain freshness and microbial activity and reactivated at $37^{\circ} \mathrm{C}$ for two days prior to use.

\subsection{Semi-Continuous Tests}

Two identical $380 \mathrm{~mL}$ single-stage continuously stirred reactors (R1, R2) (BioBLU single-use vessels, Eppendorf, Nijmegen, The Netherlands) with working volumes of $304 \mathrm{~mL}$ were established to perform the semi-continuous digestion tests [29]. The OLR and process conditions used in the semi-continuous experiment are given in Table 2.

The vessels were placed in a temperature-controlled water bath $\left(36^{\circ} \mathrm{C}\right)$ and fed once a day. The PFSF solution was impelled with a syringe pump (NE1000, World Precision Instruments, Sarasota, Florida, USA), $30 \mathrm{~mL}$ syringes (inner diameter $23.1 \mathrm{~mm}$ Terumo) and tubing (Teflon, outer diameter $1.37 \mathrm{~mm}$, inner diameter $1.07 \mathrm{~mm}$ ). 
Table 2. Process conditions applied in the semi-continuous tests.

\begin{tabular}{cccccc}
\hline Reactors & $\begin{array}{l}\text { IN1 } \\
\mathbf{( \% )}\end{array}$ & $\begin{array}{c}\text { IN2 } \\
\mathbf{( \% )}\end{array}$ & $\begin{array}{c}\text { Organic Load } \\
(\mathbf{g ~ V S}\end{array}$ & $\begin{array}{c}\text { Temperature } \\
\left({ }^{\circ} \mathbf{C}\right)\end{array}$ & $\begin{array}{c}\text { HRT } \\
\text { (d) }\end{array}$ \\
\hline R1 & 25 & 75 & 1.5 & 36 & 20 \\
R2 & 25 & 75 & 1.5 & 36 & 20 \\
\hline
\end{tabular}

IN1: digestate from reactor treating activated sludge, IN2: digestate from reactor treating organic fraction of MSW, IN3: digested cow manure.

\subsection{Analytical Methods}

Total and volatile solids $\left(\mathrm{g} \cdot \mathrm{kg}^{-1}\right)$ were estimated according to the Standard Methods of APHA (2005) [30]. pH was calculated using a pH meter (HI991001, Hanna Instruments, Woonsocket, Rhode Island, USA). Chemical oxygen demand $\left(\mathrm{g} \cdot \mathrm{kg}^{-1}\right)$ and ammonium $\left(\mathrm{g} \cdot \mathrm{kg}^{-1}\right)$ were estimated using assay test kits (Hach Lange $\mathrm{GmbH}$, Germany) and were quantified by a spectrophotometer (DR3900, Hach, Loveland, Colorado, USA). Free ammonia nitrogen (FAN; $\mathrm{g} \cdot \mathrm{kg}^{-1}$ ) was calculated based on the equation [31]:

$$
\mathrm{N}-\mathrm{NH}_{3}=\frac{\mathrm{TAN} \times 10^{\mathrm{pH}}}{\mathrm{e}^{\left(\frac{6344}{273.15+\mathrm{T}}\right)}+10^{\mathrm{pH}}}
$$

Total alkalinity $\left(\mathrm{g} \mathrm{CaCO}_{3} \cdot \mathrm{L}^{-1}\right)$, total volatile fatty acids (TVFA; mg acetate/L), FOS/TAC (TVFA/TA) ratio were determined using Nordmann titration method. The biogas volume

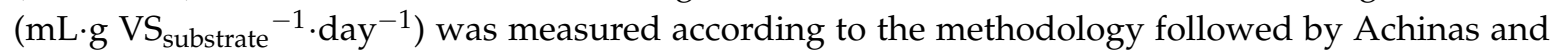
Euverink [20]. The methane content was determined with a micro gas chromatography (GC) device (single channel 2-stream selector system, Thermo Fisher Scientific Inc, Waltham, MA, USA) equipped with a chromatographic column (PLOT-U). Helium was used as carrier gas at atotal flow of $10 \mathrm{~mL} \cdot \mathrm{min}^{-1}$. A gas standard consisting of $50 \%(\mathrm{v} / \mathrm{v}) \mathrm{CH}_{4}, 20 \%(\mathrm{v} / \mathrm{v}) \mathrm{CO}_{2}$ and $30 \%(\mathrm{v} / \mathrm{v}) \mathrm{N}_{2}$ was used to calibrate the micro GC device.

\subsection{Statistical Analysis}

Statistical significance of the data was determined by one-way ANOVA using Microsoft Office Excel (Microsoft, Redmond, WA, USA) with a threshold p-value of 0.05 .

\subsection{Economics}

As for all investments, the economic assessment is a pivotal factor for the final decision (go/no-go) to continue with a project. In this part, the costs and revenues of a biogas installation treating fine sieve fraction are discussed. The AD plant comprises investment costs, operation and maintenance costs, insurance and taxes. The investment costs for a biogas unit depends on the specific needs of the installation. As a result, it is difficult to clarify investment costs beforehand. For better comprehension, it is indispensable to state that the total cost of installation for a biogas power plant can vary from $2500 €$ to $7500 €$ per $\mathrm{kWh} / \mathrm{h}$ electricity generation [32]. In this study, the equation estimating the total capital investment (TCI) is:

$$
\mathrm{TCI}=\mathrm{TIC} \cdot \mathrm{P}_{\mathrm{el}}
$$

where TCI is total capital investment $(€)$, TIC is total installation cost per power installed $(€ / \mathrm{kW})$, and $\mathrm{P}_{\mathrm{el}}$ is total power installed $(\mathrm{kW})$. It is possible to estimate also the electricity yield (E) and the heat yield $(\mathrm{H})$ multiplying the total methane by specific conversion factors: for electricity the conversion factor is included between 1.8 and $2.2 \mathrm{kWhe}[33,34]$, whereas the heat conversion factor could vary from $2 \mathrm{kWh} / \mathrm{m}^{3}$ biogas to $3 \mathrm{kWh} / \mathrm{m}^{3}$ biogas [33]. In this study, the average values are considered using the following equations:

$$
\begin{aligned}
& \mathrm{E}(\mathrm{kWhe})=\text { Total Methane } \cdot 2 \\
& \mathrm{H}(\mathrm{kWh})=\text { Total Methane } \cdot 2.5
\end{aligned}
$$


To evaluate the profitability of the installation, NPV, IRR and PP concepts were used as valuation criteria. NPV analysis is a form of intrinsic valuation and is used extensively across finance for determining the value of a business project investment. The NPV is the sum of expected net cash flows measured in today's currency and is given by:

$$
\mathrm{NPV}=-\mathrm{I}+\sum_{\mathrm{t}=0}^{\mathrm{n}} \frac{\mathrm{CAF}_{\mathrm{t}}}{(1+\mathrm{r})^{\mathrm{t}}}
$$

and:

$$
\mathrm{CAF}_{\mathrm{t}}=\mathrm{p}_{\mathrm{t}} \mathrm{Y}_{\mathrm{i}}-\mathrm{v}_{\mathrm{t}} \mathrm{Z}_{\mathrm{i}}
$$

where CAF is expected cash flow at time $t, r$ is discount factor, and $I$ is initial capital investment cost. CAF is a function of income $p_{t}$ from i outputs $(Y)$ where output relates to electricity and heat (no income from digestate sale is assumed) and cost $v_{t}$ from $i$ inputs $(Z)$ where input include total operating and maintenance costs including labor cost (no cost for feedstock supply and digestate disposal are assumed). IRR is the discount rate for which the total present value of cash flows equals cost of investment. if the IRR is greater than or equal to the cost of capital, the investor can accept the project as a good investment.

\section{Results}

\subsection{Experimental Study}

The batch test results showed that combined inoculation can enhance the biogas production when using digested activated sludge with digested organic fraction of MSW in a ratio of 25:75 [20]. Semi-continuous reactors were established and operated at $36{ }^{\circ} \mathrm{C}$ to evaluate the process for 95 days (4.75 HRT). The results of pH, redox, FAN, FOS/TAC, and biogas yield are depicted in Figures 1 and 2. The process stability was evaluated in terms of the aforementioned parameters, which were relatively constant for all the reactors during the experiment [35].

The co-inoculated reactor R1 reached $188 \mathrm{~mL} \cdot$ day $^{-1} \cdot \mathrm{g} \mathrm{VSsubstrate}^{-1} 12.6 \%$ higher than that in reactor R2 $\left(167 \mathrm{~mL} \cdot\right.$ day $^{-1} \cdot \mathrm{g}$ VSsubstrate ${ }^{-1}$ (Figure 1). The methane content in the biogas from reactor R1 $64.7 \%$ slightly higher than the methane content of $61.4 \%$ in the biogas from R2. The daily biogas production rate increased in the first 3 weeks and became stable for the next ten weeks. The $\mathrm{pH}$ of the reactor content is an important parameter to evaluate the $\mathrm{AD}$ performance. This is due to the high sensitivity of the methanogens to $\mathrm{pH}$ variations [36]. Several reports refer to a $\mathrm{pH}$ range of 6.8-7.2 as optimum for the activity of the methanogens $[37,38]$. The $\mathrm{pH}$ also affects the other microbial activities and thus the digester conversion efficiency. A low $\mathrm{pH}$ significantly decreases the reactor performance.

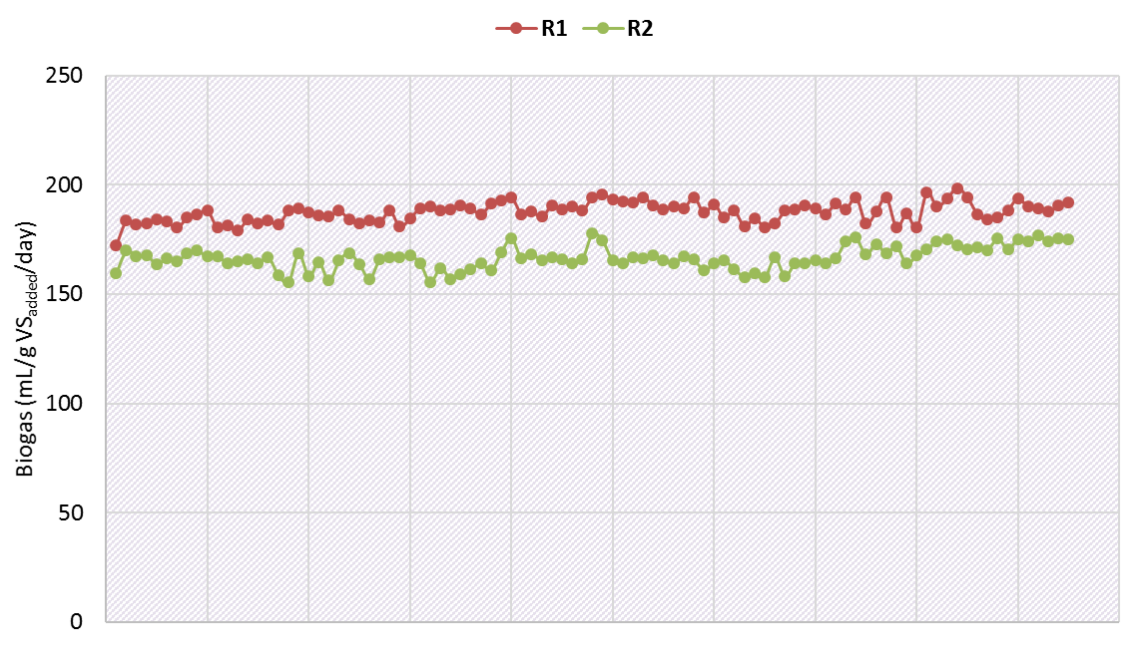

Figure 1. Cont. 

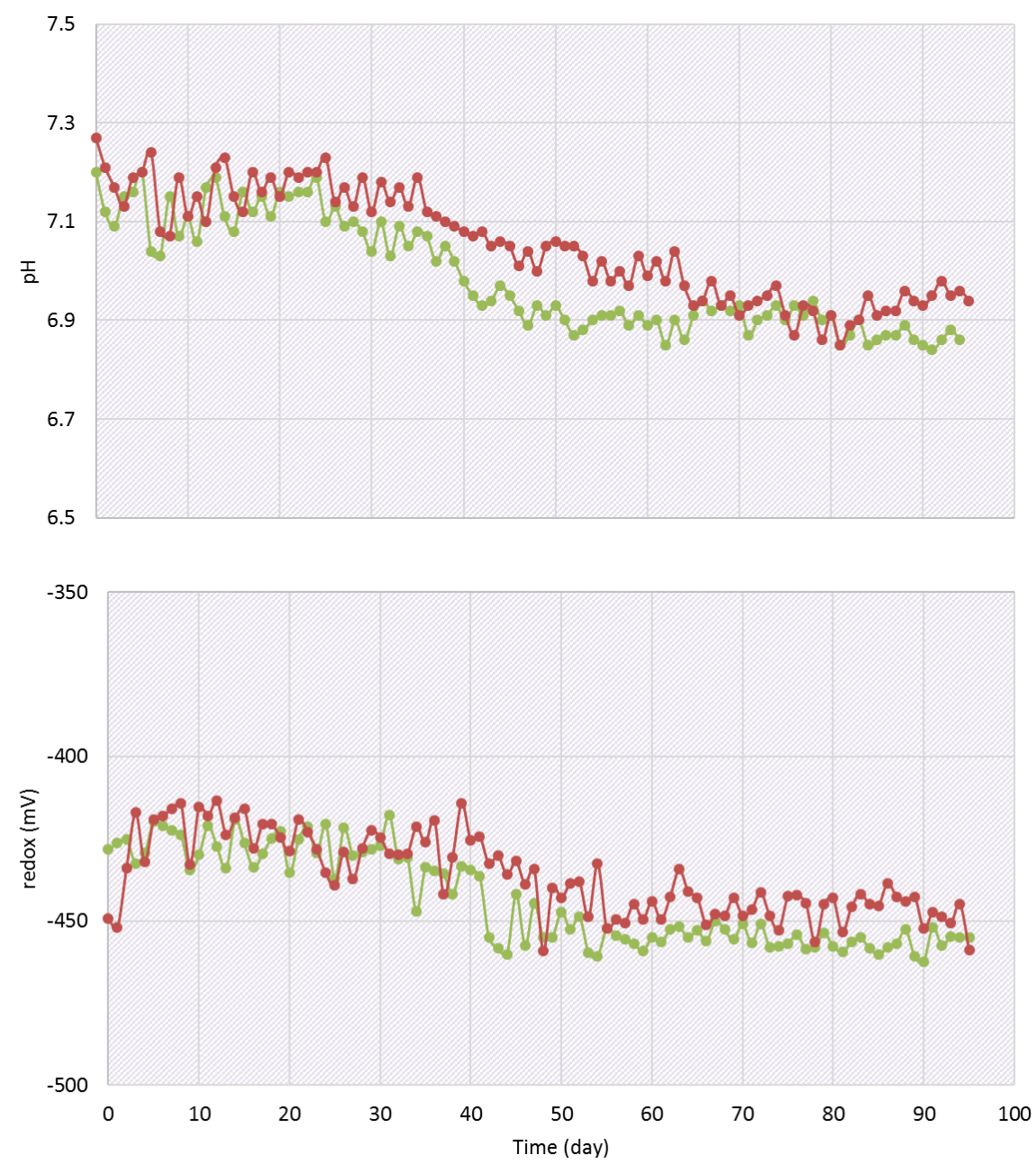

Figure 1. Evolution of biogas yield, $\mathrm{pH}$, and redox during the semi-continuous experiment.

The $\mathrm{pH}$ range for the co-inoculated reactors was between $6.84-7.28$ for $\mathrm{R} 1$ and $6.85-7.27$ for R2 (Figure 1). Preceding studies also state that different microbial species have specific $\mathrm{pH}$ values for optimal activity $[39,40]$.

Concentration of volatile fatty acids and total alkalinity in the reactors were monitored daily and were plotted as FOS/TAC ratio in Figure 2.

The significant higher buffer capacity in the co-inoculated reactors resulted in an optimal $\mathrm{pH}$ for the methanogenic bacteria. No extra alkalinity was added in these reactors and the inocula were considered as the only source of alkalinity. The FOS/TAC ratio in reactor R1 ranged between $0.14-0.26$ whereas the ratio $\mathrm{n}$ in reactor $\mathrm{R} 2$ lied between $0.11-0.29$. If the FOS/TAC ratio falls in the range of values between 0.20 and 0.3 , the anaerobic digestion process is then considered as stable. With a ratio of less than 0.20 , the microbes begin to "feel hungry" and require the decrease of the inoculum-to-substrate ratio, while a value greater than 0.3 indicates the beginning of "indigestion" [41-43].

The evolution of free ammonia (FAN) increased faster in reactor R1 during the experimental period and reached a $12 \%$ higher steady state value than in reactor R2 (Figure 2). FAN is partly free ammonia $\left(\mathrm{NH}_{3}\right)$ that is able to penetrate a bacterial cell membrane resulting in a proton imbalance that results in an increased intercellular $\mathrm{pH}$, inhibiting specific enzyme responses, and increasing maintenance energy requirements $[44,45]$. Inferences redounded from long-term continuously operated reactors, showed that adaptation of anaerobic digestion to high FAN (up to $1 \mathrm{~g} \cdot \mathrm{L}^{-1}$ ) is possible, most likely as a result of an increase in specific ammonia tolerant species [46,47]. Considering the above findings, the co-inoculation represents an efficient solution for digesters as well as a sustainable solution with 
ecological benefits. A financial evaluation is interesting to assess other factors than the mixing ratio for full-scale applications.

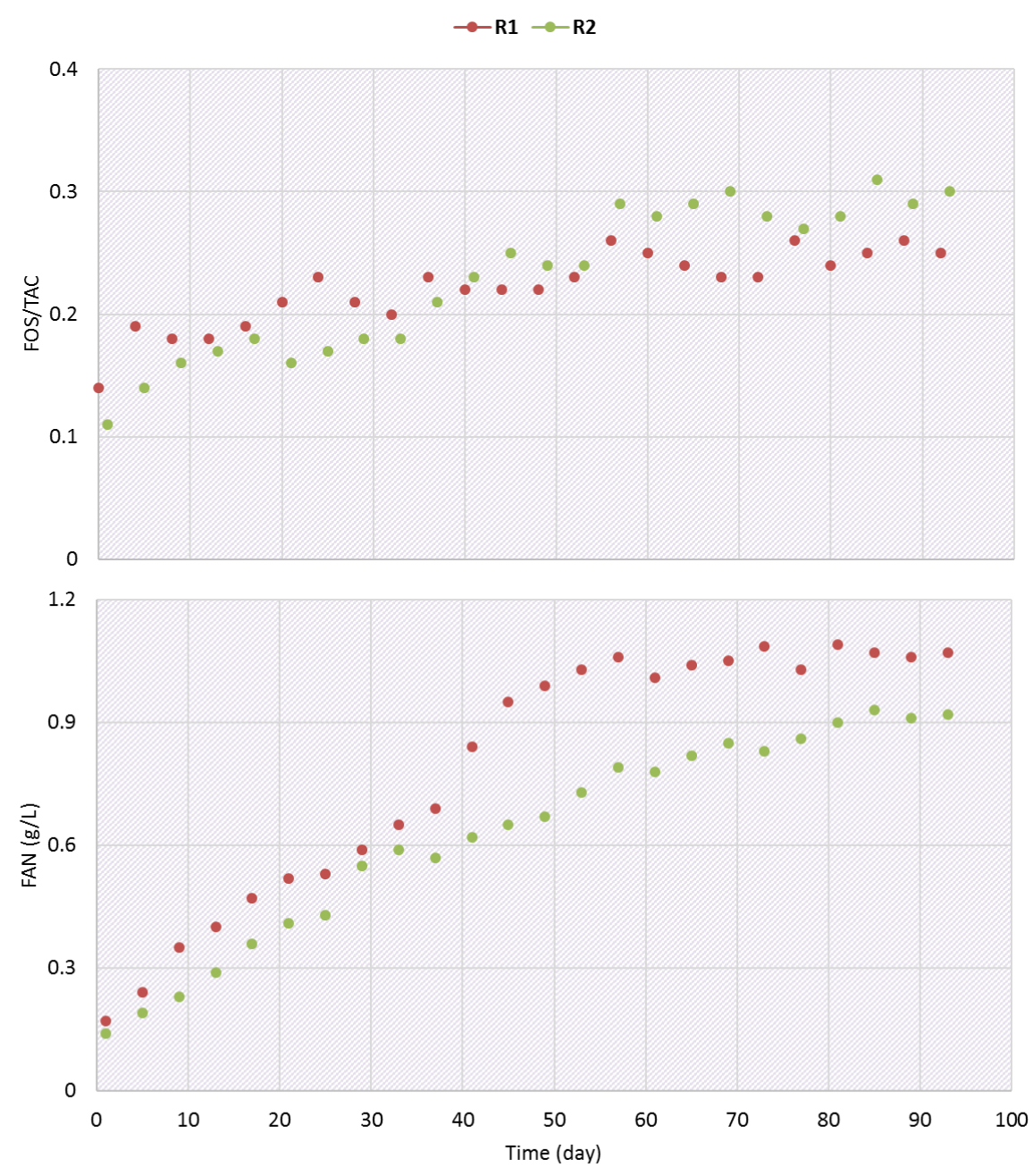

Figure 2. Evolution of FOS/TAC and FAN during the semi-continuous experiment.

\subsection{Feasibility Study}

The biogas yield, methane content, and AD performance from the experimental study support the financial assessment. The annual consumption of toilet paper in the Netherlands is approximately 180 kton [48]. Assuming 70\% recovery, the FSF that can be annually extracted from waste water treatment plants is up to 126 kton (dry basis) or 630 kton pressed FSF (wet basis). In our study, we examined the case of $10 \mathrm{kton}$ pressed FSF (wet basis) that corresponds to $1.6 \%$ of the total capacity of pressed FSF treatment potential in The Netherlands. To have a prudential assessment and avoid overestimation, the values of Table 3 were set for the base scenario of the biogas installation:

Investment is paid from own equity capital (100\% down payment) with no borrowed capital (i.e., loan) or subsidy. We assumed 12 years as the average life-span of the installation with a discount rate of $7 \%$. In addition, costs for the maintenance of digester and CHP unit are included in the for the operation and maintenance in the O\&M cost.

The base scenario produces $39 \mathrm{kWh}$ per ton feedstock digested based on the values of Table 4 . Further to the biogas quantity, the economic analysis for the biogas plant that used pressed fine sieve fraction as a substrate has been examined for the NPV concept. Higher NPV values represent greater economic benefits. In a "no subsidy" situation, the plant has 11 years payback time (PP), and showing a positive NPV of $11,240 €$ and IRR of $8 \%$ (Figure 3). 
Table 3. Average values for techno-economic parameters used in the NPV analysis.

\begin{tabular}{ccc}
\hline Parameter & Unit & Base Scenario \\
\hline Biogas yield & $\mathrm{m}^{3} \cdot \mathrm{g} \mathrm{VS}^{-1}$ & 177.5 \\
$\mathrm{CH}_{4}$ content & $\%$ & 63 \\
Electricity produced from $1 \mathrm{~m}^{3} \mathrm{CH}_{4}$ & $\mathrm{kWh}$ & 2 \\
Heat produced from $1 \mathrm{~m}^{3} \mathrm{CH}_{4}$ & $\mathrm{kWh}$ & 2.5 \\
Total installation cost (TIC) & $€ \cdot \mathrm{kW}_{\text {installed }}$ & 6000 \\
Operational \& maintenance cost & $€ \cdot \mathrm{kWh}^{-1}$ & 0.065 \\
Extraordinary generator cost & $€ \cdot \mathrm{kWh}^{-1}$ & 0.002 \\
Extraordinary plant cost & $€ \cdot \mathrm{kWh}^{-1}$ & 0.005 \\
Transport cost & $€ \cdot \mathrm{ton}^{-1}$ & 2.5 \\
Electricity price & $€ \cdot \mathrm{kWh}^{-1}$ & 0.11 \\
Heat price & $€ \cdot \mathrm{GJ}^{-1}$ & 30 \\
\hline
\end{tabular}

Table 4. Technical data for the biogas plant.

\begin{tabular}{ccc}
\hline & Unit \\
\hline PFSF digested & ton $^{3}$ year $^{-1}$ & 10,000 \\
Biogas produced & $\mathrm{m}^{3} \cdot$ year $^{-1}$ & 309,571 \\
Methane produced & $\mathrm{m}^{3} \cdot$ year $^{-1}$ & 195,030 \\
Operating time & hour & 8040 \\
Electrical energy produced & $\mathrm{MWh}$ & 390 \\
Heat energy produced & $\mathrm{GJ}$ & 1755 \\
Total power installed-Pel. & $\mathrm{kW}$ & 49 \\
\hline
\end{tabular}

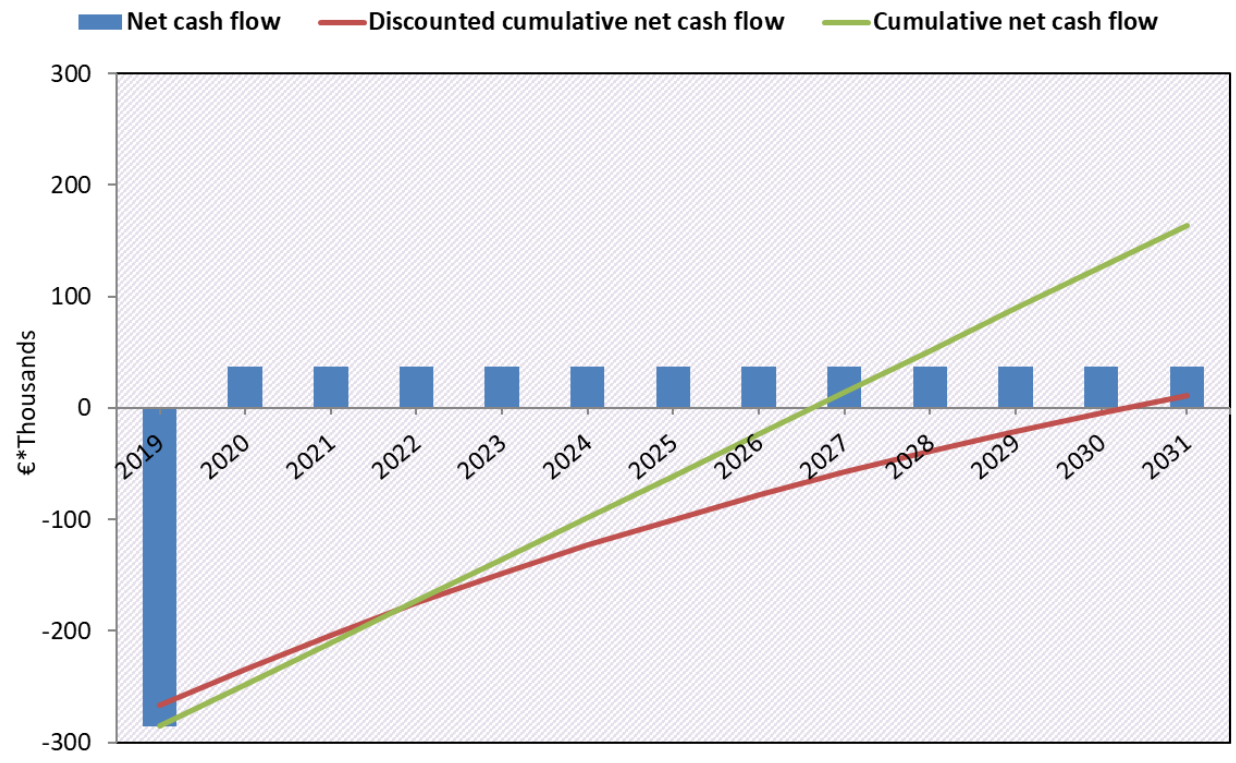

Figure 3. Economic results of the base case study based on the NPV model.

Table 5 shows the investment costs, revenues, gross cash flows, net present value, internal rate return, and payback period time for the case study of the base scenario. According to Equation (6), the total capital investment is approximately estimated up to $300,000 €$. The total revenue is $95,565 €$ and the net cash flow is $37,458 €$ for each year. It is notable that an external subsidy might play a significant role in the profitability of the plant and makes the choice for a $300 \mathrm{k} €$ investment somewhat easier. 
Table 5. Economic results of the case study based on the NPV model.

\begin{tabular}{|c|c|c|c|c|c|c|c|c|}
\hline & & Present & $\begin{array}{c}\text { Year } \\
1\end{array}$ & $\begin{array}{c}\text { Year } \\
2\end{array}$ & $\begin{array}{c}\text { Year } \\
3\end{array}$ & $\begin{array}{c}\text { Year } \\
6\end{array}$ & $\begin{array}{c}\text { Year } \\
9\end{array}$ & $\begin{array}{c}\text { Year } \\
12\end{array}$ \\
\hline \multicolumn{9}{|l|}{ Investment } \\
\hline Paid capital & & $-291,089$ & - & - & - & - & - & - \\
\hline$O \& M$ cost & & & $-25,354$ & $-25,354$ & $-25,354$ & $-25,354$ & $-25,354$ & $-25,354$ \\
\hline EGM cost & & & -780 & -780 & -780 & -780 & -780 & -780 \\
\hline EPM cost & & & -1950 & -1950 & -1950 & -1950 & -1950 & -1950 \\
\hline Transport cost & & & $-25,000$ & $-25,000$ & $-25,000$ & $-25,000$ & $-25,000$ & $-25,000$ \\
\hline Total & & $-291,089$ & $-53,084$ & $-53,084$ & $-53,084$ & $-53,084$ & $-53,084$ & $-53,084$ \\
\hline \multicolumn{9}{|l|}{ Revenues } \\
\hline Electricity revenue & & & 42,907 & 42,907 & 42,907 & 42,907 & 42,907 & 42,907 \\
\hline Heat revenue & & & 52,658 & 52,658 & 52,658 & 52,658 & 52,658 & 52,658 \\
\hline Total revenues & & & 95,565 & 95,565 & 95,565 & 95,565 & 95,565 & 95,565 \\
\hline \multicolumn{9}{|l|}{ Cash flows } \\
\hline Gross cash flow & & & 42,480 & 42,480 & 42,480 & 42,480 & 42,480 & 42,480 \\
\hline EBITDA & & & 42,480 & 42,480 & 42,480 & 42,480 & 42,480 & 42,480 \\
\hline Asset value & & & 268,698 & 246,306 & 223,915 & 156,740 & 89,566 & 22,391 \\
\hline Fiscal depreciation & & & 22,391 & 22,391 & 22,391 & 22,391 & 22,391 & 22,391 \\
\hline EBIT & & & 20,089 & 20,089 & 20,089 & 20,089 & 20,089 & 20,089 \\
\hline Tax & & & 5,022 & 5,022 & 5,022 & 5,022 & 5,022 & 5,022 \\
\hline Net cash flow (NCF) & & & 37,458 & 37,458 & 37,458 & 37,458 & 37,458 & 37,458 \\
\hline Cumulative NCF & & & $-248,033$ & $-210,575$ & $-173,117$ & $-60,743$ & 51,631 & 164,005 \\
\hline Net discounted CF (NDCF) & & & 32,717 & 30,577 & 28,577 & 23,327 & 19,042 & 15,544 \\
\hline Cumulative NDCF & & & $-248,033$ & $-210,575$ & $-173,117$ & $-99,949$ & $-38,732$ & 11,240 \\
\hline Net present value (NPV) & 11,240 & & & & & & & \\
\hline Internal rate of return (IRR) & $8 \%$ & & & & & & & \\
\hline Payback period (PP) & 11 & & & & & & & \\
\hline
\end{tabular}

The NPV analysis revealed insights of the viability of a biogas plant treating PFSF. Electricity and heat prices, transport and operation cost as well as the biogas yield are pivotal decision parameters. These parameters allow model users to determine whether certain changes in the given situation (base scenario) might affect the profitability. A change of $\pm 5 \%$ and $\pm 10 \%$ on these parameters was applied to examine how they influence the profitability. Their impact on the NPV value is depicted in Figure 4.

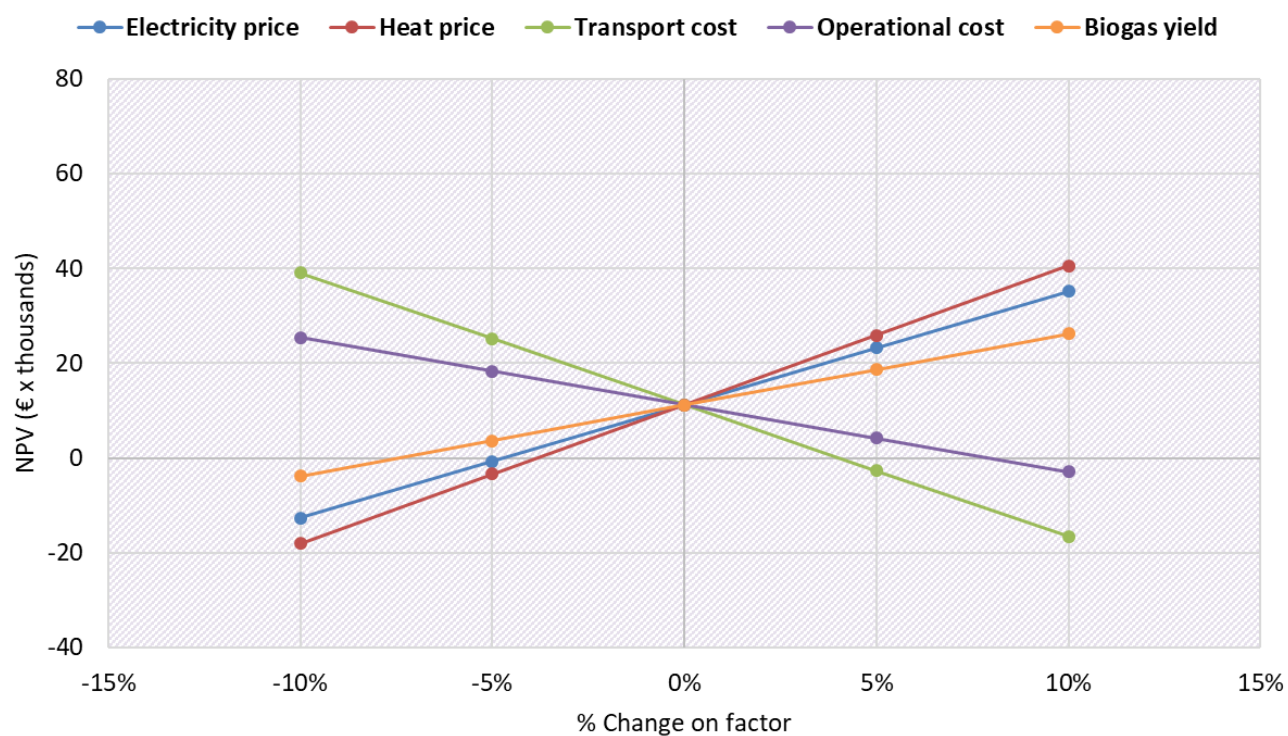

Figure 4. The influence of a $5 \%$ and $10 \%$ change of the parameters in on the profitability of a biogas plant.

\section{Conclusions}

This study aimed at exploring the feasibility of electricity generation and heat recovery from a biogas plant treating the fine sieve fraction available in The Netherlands. The NPV model was used in this study to facilitate the economic assessment. PFSF was anaerobically treated in semi-continuous mode with two different inocula. The reactors were run for 4.75 HRT and produced an average biogas 
yield of $177.5 \mathrm{~mL} \cdot$ day $^{-1} \cdot \mathrm{g}$ VSsubstrate ${ }^{-1}$. The results from the semi-continuous mode were used in the economic analysis to evaluate the feasibility of a biogas unit treating PFSF. The potential producible electricity energy and heat energy from a biogas plant treating PFSF have been $390 \mathrm{MWh}$ and $1755 \mathrm{GJ}$ per year respectively. In The Netherlands, biogas is mainly produced from the sludge that is produced in aerobic wastewater treatment and combusted for electricity generation. In addition, AD technology and policy drivers might reinforce the implementation of alternative AD pathways. This study can be further expanded to incorporate and address the assumptions and uncertainties associated with the operation costs, funding, price of feedstock purchase (if available), and the price of digestate sale and disposal. Notwithstanding, environmental and ecological assessment would be interesting in order to examine other factors than the techno-economic for full-scale applications.

Author Contributions: Writing—original draft, S.A.; Writing—review \& editing, G.J.W.E.

Funding: This research received no external funding.

Conflicts of Interest: The authors declare no conflict of interest.

\section{Abbreviations}

$\begin{array}{ll}\text { AD } & \text { anaerobic digestion } \\ \text { EBIT } & \text { earnings before interest and tax } \\ \text { EBITDA } & \text { earnings before interest, taxes, depreciation and amortization } \\ \text { EGM } & \text { extraordinary generator maintenance } \\ \text { EPM } & \text { extraordinary plant maintenance } \\ \text { EU } & \text { European Union } \\ \text { FAN } & \text { free-ammonia nitrogen } \\ \text { FOS/TAC } & \text { fatty acids/total alkalinity } \\ \text { FSF } & \text { fine sieved fraction } \\ \text { HRT } & \text { hydraulic retention time } \\ \text { IRR } & \text { internal rate of return } \\ \text { MSW } & \text { municipal solid waste } \\ \text { NPV } & \text { net present value } \\ \text { O\&M } & \text { operation and maintenance } \\ \text { OLR } & \text { organic loading rate } \\ \text { PFSF } & \text { pressed fine sieve fraction } \\ \text { PP } & \text { payback period } \\ \text { TCI } & \text { total capital investment } \\ \text { TIC } & \text { total installation cost } \\ \text { WWTP } & \text { waste water treatment plant }\end{array}$

\section{References}

1. Sahajwalla, V. Green processes: Transforming waste into valuable resources. Engineering 2018, 4, 309-310. [CrossRef]

2. Lauer, M.; Thrän, D. Flexible biogas in future energy systems-Sleeping beauty for a cheaper power generation. Energies 2018, 11, 761. [CrossRef]

3. Davis, L.A. The shale oil and gas revolution. Engineering 2018, 4, 438-439. [CrossRef]

4. Chen, P.; Anderson, E.; Addy, M.; Zhang, R.; Cheng, Y.; Peng, P.; Ma, Y.; Fan, L.; Zhang, Y.; Lu, Q.; et al. Breakthrough technologies for the biorefining of organic solid and liquid wastes. Engineering 2018, 4, 574-580. [CrossRef]

5. Matsakas, L.; Gao, Q.; Jansson, S.; Rova, U.; Christakopoulos, P. Green conversion of municipal solid wastes into fuels and chemicals. Electron. J. Biotechnol. 2017, 26, 69-83. [CrossRef]

6. RedCorn, R.; Fatemi, S.; Engelberth, A.S. Comparing end-use potential for industrial food-waste sources. Engineering 2018, 4, 371-380. [CrossRef]

7. Aryal, N.; Torben Kvist, T. Alternative of biogas injection into the Danish gas grid system-A study from demand perspective. ChemEngineering 2018, 2, 43. [CrossRef] 
8. Achinas, S.; Achinas, V.; Euverink, G.J.W. A technological overview of biogas production from biowaste. Engineering 2017, 3, 299-307. [CrossRef]

9. Solarte-Toro, J.C.; Chacón-Pérez, Y.; Cardona-Alzate, C.A. Evaluation of biogas and syngas as energy vectors for heat and power generation using lignocellulosic biomass as raw material. Electron. J. Biotechnol. 2018, 33, 52-62. [CrossRef]

10. Macedonio, F.; Drioli, E. Membrane engineering for green process engineering. Engineering 2017, 3, $290-298$. [CrossRef]

11. Achinas, S.; Achinas, V. Biogas combustion: An introductory briefing. In Biogas: Production, Applications and Global Developments; Vico, A., Artemio, N., Eds.; Nova Science Publishers, Inc.: New York, NY, USA, 2017; pp. 179-193.

12. Wang, J.; Wang, H.; Fan, Y. Techno-economic challenges of fuel cell commercialization. Engineering 2018, 4 , 352-360. [CrossRef]

13. Huarachi-Oliveraa, R.; Dueñas-Gonzab, A.; Yapo-Parib, Y.; Vegab, P.; Romero-Ugarteb, M.; Tapiab, J.; Molinab, L.; Lazarte-Riverab, A.; Pacheco-Salazarc, D.D.; Esparza, M. Bioelectrogenesis with microbial fuel cells (MFCs) using the microalgaChlorella vulgarisand bacterial communities. Electron. J. Biotechnol. 2019, 37, 34-40.

14. Chen, J.F. Green chemical engineering. Engineering 2017, 3, 283-284. [CrossRef]

15. Wen-Wei, L.; Han-Qing, Y. Advances in energy-producing anaerobic biotechnologies for municipal wastewater treatment. Engineering 2016, 2, 438-446.

16. Chen, J.F. Green chemical engineering for a better life. Engineering 2017, 3, 279. [CrossRef]

17. Nelson, M.J.; Nakhla, G.; Zhu, J. Fluidized-bed bioreactor applications for biological wastewater treatment: A review of research and developments. Engineering 2017, 3, 330-342. [CrossRef]

18. Boonpiyo, S.; Sittijunda, S.; Reungsang, A. Co-digestion of napier grass with food waste and napier silage with food waste for methane production. Energies 2018, 11, 3200. [CrossRef]

19. De Souza Guimarães, C.; da Silva Maia, D.R.; Gonçalves Serra, E. Construction of biodigesters to optimize the production of biogas from anaerobic co-digestion of food waste and sewage. Energies 2018, 11, 870. [CrossRef]

20. Achinas, S.; Euverink, G.J.W. Effect of Combined Inoculation on Biogas Production from Hardly Degradable Material. Energies 2019, 12, 217. [CrossRef]

21. Achinas, S.; Euverink, G.J.W. Consolidated briefing of biochemical ethanol production from lignocellulosic biomass. Electron. J. Biotechnol. 2016, 23, 44-53. [CrossRef]

22. Reihani, S.F.S.; Khosravi-Darani, K. Influencing factors on single-cell protein production by submerged fermentation: A review. Electron. J. Biotechnol. 2019, 37, 34-40. [CrossRef]

23. Gao, Y.; Kong, X.; Xing, T.; Sun, Y.; Zhang, Y.; Luo, X.; Sun, Y. Digestion performance and microbial metabolic mechanism in thermophilic and mesophilic anaerobic digesters exposed to elevated loadings of organic fraction of municipal solid waste. Energies 2018, 11, 952. [CrossRef]

24. Demirel, B.; Scherer, P. Trace element requirements of agricultural biogas digesters during biological conversion of renewable biomass to methane. Biomass Bioenergy 2011, 35, 992-998. [CrossRef]

25. Wagner, O.; Lackner, N.; Mutschlechner, M.; Prem, E.M.; Markt, R.; Illmer, P. Biological pretreatment strategies for second-generation lignocellulosic resources to enhance biogas production. Energies 2018, 11, 1797. [CrossRef]

26. Chiumenti, A.; Boscaro, D.; da Borso, F.; Sartori, L.; Pezzuolo, A. Biogas from fresh spring and summer grass: Effect of the harvesting period. Energies 2018, 11, 1466. [CrossRef]

27. Ranieri, L.; Mossa, G.; Pellegrino, R.; Digiesi, S. Energy recovery from the organic fraction of Municipal Solid Waste: A real options-based facility assessment. Sustainability 2018, 10, 368. [CrossRef]

28. Ghasimi, D.S.M.; de Kreuk, M.; Maeng, S.K.; Zandvoort, M.H.; van Lier, J.B. High-rate thermophilic bio-methanation of the fine sieved fraction from Dutch municipal raw sewage: Cost-effective potentials for on-site energy recovery. Appl. Energy 2016, 165, 569-582. [CrossRef]

29. Kasprzycka, A.; Kuna, J. Methodical aspects of biogas production in small-volume bioreactors in laboratory investigations. Energies 2018, 11, 1378. [CrossRef]

30. Eaton, A.D.; American Public Health Association; American Water Works Association; Water Environment Federation. Standard Methods for the Examination of Water and Wastewater; APHA-AWWA-WEF: Washington, DC, USA, 2005. 
31. Anthonisen, A.C.; Loehr, R.C.; Prakasam, T.B.S.; Srinath, E.G. Inhibition of nitrification by ammonia and nitrous acid. J. Water Pollut. Control Fed. 1976, 48, 835-849. [PubMed]

32. German Solar Energy Society and Ecofys. Planning and Installing Bioenergy System: A Guide for Installers, Architect and Engineers, 1st ed.; James \& James: London, UK, 2005.

33. Piccinini, S. Le tecnologie di produzione del biogas. In Proceedings of the Seminar on IL Biogas: Modello di Calcolo a Supporto Della Fattibilità Tecnico-Economica (C.R.P.A.), Reggio Emilia, Italy, 30 May 2007.

34. Ragazzoni, A.; Navarrotto, P.; Castellini, A.; devenuto, L.; Barbanti, L.; Capponi, S.; Banzato, D. Biogas. Come ottenere reddito per l"agricoltura; Edizioni L"Informatore Agrario S.p.A.: Verona, Italy, 2010.

35. IEA Bioenergy. Process Monitoring in Biogas Plants; Technical Brochure; IEA Bioenergy: Paris, France, 2013; p. 39.

36. Świątek, M.; Lewicki, A.; Szymanowska, D.; Kubiak, P. The effect of introduction of chicken manure on the biodiversity and performance of an anaerobic digester. Electron. J. Biotechnol. 2018. [CrossRef]

37. Carotenuto, C.; Guarino, G.; Mario Minale, M. Temperature and $\mathrm{pH}$ effect on methane production from buffalo manure anaerobic digestion. Int. J. Heat Technol. 2016, 34, 425-429. [CrossRef]

38. Franchi, O.; Rosenkranz, F.; Chamy, R. Key microbial populations involved in anaerobic degradation of phenol and p-cresol using different inocula. Electron. J. Biotechnol. 2018, 35, 33-38. [CrossRef]

39. Lindner, J.; Zielonka, S.; Oechsner, H.; Lemmer, A. Effect of different $\mathrm{pH}$-values on process parameters in two-phase anaerobic digestion of high-solid substrates. Environ. Technol. 2015, 36, 198-207. [CrossRef] [PubMed]

40. Fox, P.; Pohland, G.K. Anaerobic treatment applications and fundamentals: Substrate specificity during phase separation. Water Environ. Res. 1994, 66, 716-724. [CrossRef]

41. Pontoni, L.; Panico, A.; Salzano, E.; Frunzo, L.; Iodice, P.; Pirozzi, F. Innovative parameters to control the efficiency of anaerobic digestion process. Chem. Eng. Trans. 2015, 43, 2089-2094.

42. Andreozzi, R.; Di Somma, I.; Esposito, G.; Pontoni, L. From organic waste to bioenergy: Efficiency, reliability and safety aspects relating to biogas production, purification and utilization. In Environmental Science and Engineering Volume 5: Solid Waste Management; Sharma, U.C., Singh, N., Gurjar, B.R., Govil, J.N., Eds.; Studium Press LLC: Houston, TX, USA, 2017.

43. Rosato, M.A. Redimensioning the Importance of the VFA/TA (FOS/TAC) Method. Available online: https:/ /agronotizie.imagelinenetwork.com/bio-energie-rinnovabili/2015/01/08/ridimensionandolrsquoimportanza-del-test-fostac/41369 (accessed on 17 March 2019).

44. Ariunbaatar, J.; Scotto Di Perta, E.; Panico, A.; Frunzo, L.; Esposito, G.; Lens, P.N.L.; Pirozzi, F. Effect of ammoniacal nitrogen on one-stage and two-stage anaerobic digestion of food waste. Waste Manag. 2015, 38, 388-398. [CrossRef] [PubMed]

45. Akindele, A.; Sartaj, M. The toxicity effects of ammonia on anaerobic digestion of organic fraction of municipal solid waste. Waste Manag. 2018, 71, 757-766. [CrossRef]

46. Calli, B.; Mertoglu, B.; Inanc, B.; Yenigun, O. Effects of high free ammonia concentrations on the performances of anaerobic bioreactors. Process Biochem. 2005, 40, 1285-1292. [CrossRef]

47. Sun, L.; Müller, B.; Westerholm, M.; Schnürer, A. Syntrophic acetate oxidation in industrial CSTR biogas digesters. J. Biotechnol. 2014, 171, 39-44. [CrossRef]

48. The Dutch Have Built a Cycle Lane from Used Toilet Paper. Available online: https:/ /www.weforum.org/ agenda/2017/10/the-dutch-have-built-a-cycle-lane-from-used-toilet-paper/ (accessed on 17 March 2019).

(C) 2019 by the authors. Licensee MDPI, Basel, Switzerland. This article is an open access article distributed under the terms and conditions of the Creative Commons Attribution (CC BY) license (http://creativecommons.org/licenses/by/4.0/). 